\title{
PENGEMBANGAN MODUL FISIKA KONTEKSTUAL INTERAKTIF BERBASIS WEB UNTUK MENINGKATKAN PEMAHAMAN KONSEP DAN HASIL BELAJAR FISIKA SISWA SMA DI SINGARAJA
}

\author{
Rai Sujanem \\ Jurusan Pendidikan Fisika FMIPA Udiksha
}

\begin{abstract}
Abstrak
Tujuan utama penelitian ini adalah untuk 1) menyusun dan mengembangkan modul fisika kontekstual interaktif berbasis web untuk siswa kelas XII SMA, 2) menjelaskan perbedaan pengaruh antara modul fisika kontekstual interaktif berbasis web (MKIW) dan modul kontekstual konvensional (MKK) terhadap pemahaman konsep siswa dalam pembelajaran fisika, dan 3) menjelaskan perbedaan pengaruh antara MKIW dan MKK terhadap hasil belajar siswa dalam pembelajaran fisika.

Untuk mencapai tujuan tersebut dilakukan penelitian dalam dua tahap, pertama, pengembangan produk modul fisika kontekstual, dan kedua, eksperimen untuk menguji keunggulan komparatif produk. Pengembangan produk menggunakan desain model Dick dan Carey. Proses pengembangan mendasarkan diri pada analisis kebutuhan. Salah satu pendukungnya adalah studi pendahuluan di SMA-SMA di Singaraja Bali. Proses pengembangan menggunakan instrumen-instrumen: angket fasilitas pendukung pembelajaran berbasis teknologi informasi dan komunikasi (TIK), angket kompetensi guru dan siswa dalam TIK, angket ahli isi, angket ahli media, angket siswa perorangan, angket siswa kelompok kecil, dan anget respon implementasi pada pembelajaran. Instrumeninstrumen tersebut memenuhi persyaratan validitas isi. Studi pendahuluan melibatkan 320 siswa kelas XII SMA, 12 orang guru TIK, dan 30 guru fisika. Proses uji formatif melibatkan 3 ahli isi dan media pembelajaran, 3 ahli desain, 6 siswa perorangan, 12 siswa kelompok kecil, dan 3 orang guru. Dalam implementasi modul fisika kontekstual dilakukan dengan penelitian kuasi eksperimen dengan model unequivalence pretest-posttest control group design. Populasi penelitian adalah siswa-siswa kelas XII SMA di kota Singaraja pada semester I tahun 2010/2011. Pengambilan sampel eksperimen dilakukan dengan teknik random kelompok bertahap. Berdasarkan tehnik tersebut, terpilih kelompok-kelompok siswa yang belajar dengan fasilitas MKIW dan kelompok-kelompok siswa yang belajar dengan fasilitas MKK adalah SMAN 1, SMAN 2, SMAN 3, dan SMAN 4 Singaraja. Instrumen yang digunakan dalam eksperimen adalah tes pemahaman konsep dan tes hasil belajar. Instrumen tes pemahaman konsep terdiri 12 butir dengan internal consistency bergerak dari $r=0,40$ sampai dengan $r=0,69$, dan alpha Cronbach=0,713. Instrumen tes hasil belajar terdiri 12 butir dengan internal consistency bergerak dari $r=0,34$ sampai dengan $r=0,77$, dan alpha Cronbach $=0,733$. Analisis data dilakukan dengan statistik deskriptif dan Multivariat analysis of covariance (MANCOVA). Tehnik analisis menggunakan program SPSS 17.0 FW dengan pengujian hipotesis dilakukan pada taraf signifikansi 5\%.
\end{abstract}


Berdasarkan hasil analisis data, ditemukan hasil-hasil penelitian seperti berikut. Pertama, hasil penelitian pengembangan produk mengungkapkan temuan seperti berikut. (1) Delapan modul fisika kontekstual interaktif berbasis web berikut lembaran kerja siswa (LKS), tes pemahaman konsep, dan tes hasil belajar. Modul fisika kontekstual interaktif berbasis web yang dikembangkan berisikan komponen-komponen: (a) masalah-masalah autentik yang ada di sekitar kehidupan siswa, (b) miskonsepsi dan sangkalan, (c) konsep dan prinsip esensial dan strategis, (d) contoh-contoh konseptual dan kontekstual, dan (e) pertanyaan konseptual dan kontekstual yang memandu pemerolehan pemahaman konsep dan hasil belajar. Komponen-komponen modul fisika kontekstual interaktif berbasis web dikemas dalam bentuk animasi teks, gambar, foto, dan video. Hasil uji ahli isi, ahli media, ahli media, ahli desain, siswa perorangan, siswa kelompok kecil, dan guru terhadap pengembangan draft modul fisika kontekstual interaktif berbasis web menyatakan bahwa sosok modul tersebut memiliki kelayakan untuk diimplementasikan dalam pembelajaran. Kelayakan pakai tersebut ditinjau dari segi substansi modul fisika kontekstual. Hasil penilaian para responden terhadap komponen-komponen modul tersebut adalah sesuai, baik dan sangat baik. 2) Telah berhasil dikembangkan panduan modul fisika kontekstual interaktif berbasis web bagi guru yang berisikan tentang panduan implementasi modul dalam pembelajaran. 3) Telah berhasil dikembangkan panduan modul fisika kontekstual interaktif berbasis web bagi siswa yang berisikan tentang implementasi modul dalam pembelajaran. Kedua, profil pengetahuan awal siswa terhadap konsep-konsep gelombang sebagian besar masih diwarnai miskonsepsi (27,5\% untuk model MKIW dan 30,8\% untuk model MKK). Setelah eksperimen, profil miskonsepsi siswa mengalami penurunan menjadi 13,3\% untuk kelompok model MKIW dan 19,0\% untuk kelompok MKK. Secara deskriptif setelah perlakuan kelompok MKIW relatif lebih berhasil menurunkan jumlah siswa yang mengalami miskonsepsi dibandingkan dengan MKK. Ketiga, uji komparasi produk menunjukkan hasil-hasil sebagai berikut. 1) Terdapat perbedaan signifikan pemahaman konsep antara kelompok MKIW dan MKK $(\mathrm{F}=53.868$; $\mathrm{p}<0,05$. Nilai rata-rata pemahaman konsep kelompok MKIW lebih tinggi dibandingkan dengan kelompok MKK $(\Delta \mu=5,525$; $\mathrm{SD}=0,573, \mathrm{p}<0,05)$. 2) Terdapat perbedaan signifikan hasil belajar antara kelompok MKIW dan MKK ( $F=5,716 ; p<0,05$. Nilai rata-rata hasil belajar kelompok MKIW lebih tinggi dibandingkan dengan kelompok $\operatorname{MKK}(\Delta \mu=2,841 ; \mathrm{SD}=1,188, \mathrm{p}<0,05)$.

Oleh karena modul fisika kontekstual interaktif berbasis web untuk kelas XII SMA yang telah dikembangkan dalam penelitian ini layak, efektif, dan unggul dalam meningkatkan pemahaman konsep dan hasil belajar siswa, maka dalam pembelajaran fisika di SMA hendaknya menggunakan modul fisika kontekstual interaktif berbasis web sebagai fasilitas belajar.

Kata-kata kunci : modul fisika kontekstual - interaktif - web- pemahaman - hasil belajar. 


\section{Pendahuluan}

Sampai saat ini, masalah yang melanda dunia pendidikan fisika sebagian besar berkutat di sekitar upaya meningkatkan pemahaman konsep siswa. Pemahaman konsep dan hasil belajar fisika siswa, khusus siswa SMA dalam belajar fisika masih relatif rendah, karena pengemasan pendidikan sering tidak sejalan dengan hakekat belajar dan mengajar fisika (Degeng dalam Santyasa, 2004; Brook \& Brook, 1993). Untuk itu perlu dirancang pengemasan pendidikan yang sejalan dengan hakekat belajar dan mengajar yakni : bagaimana siswa belajar, bagaimana guru mengajar, bagaimana pesan pembelajaran di dalam bahan ajar itu, bukan semata-mata pada hasil belajar (Brook \& Brook, 1993, Lawson, 1998, Novak, 1985). Pengemasan bahan ajar fisika dan implementasinya hendaknya diorientasikan pada penyediaan peluang kepada siswa dalam pencapaian pemahaman dan hasil belajar siswa SMA.

Pengemasan bahan ajar fisika selama ini masih bersifat linier, yaitu : bahan ajar yang hanya menyajikan konsep dan prinsip, contoh-contoh soal dan pemecahannya, dan soal-soal latihan. Kemasan buku ajar fisika yang digunakan sebagai pegangan siswa maupun guru belum dikemas secara komprehensip yang berisikan sajian masalah real, miskonsepsi, konsep-konsep esensial, contoh konseptual dan kontekstual, yang mengintegrasikan teknologi serta dalam lingkungan problem-based learning (PBL). Strategi PBL merupakan pembelajaran yang menyajikan masalah sebagai rangsangan (stimulus) untuk belajar. Masalah yang disajikan sangat kompleks dan tak terstruktur serta berhubungan dengan dunia siswa (Savoi, 1994, Barbara,1995, Gijselaers, 1996, Barrows, 1996, Ibrahim, et al., 2004).

Perkembangan teknologi informasi dan komunikasi (ICT) khususnya internet memberi peluang dunia pendidikan untuk mengakses berbagai informasi baik berbentuk teks, gambar, simulasi, maupun suara (Hardjito, 2005, Siahaan, 2002, Candiasa, 2005). Pengintegrasian TIK dalam dunia pendidikan, khususnya berkaitan dengan kemasan pembelajaran berbasis web dalam lingkungan PBL membawa revolusi baru dan memberi peluang pencapaian pemahaman dan hasil belajar yang lebih tinggi (IHEP, dalam Oliver, 2002, Duffy \& Cunningham, 1996, Jonassen, dalam Liu, 2005, Willian, et al, 1998). 
Namun, pengintegrasian teknologi khususnya media berbasis TIK dalam pembelajaran belum dimanfaatnkan secara optimal, padahal fasilitas penunjang pembelajaran berbasis TIK yang tersedia di SMA-SMA di Singaraja cukup memadai (Sujanem, et al, 2008, Sujanem, et al, 2009). Demikian pula dengan kompetensi Guru dan siswa dalam bidang TIK juga cukup memadai, namun pembelajaran berbasis web belum dapat dilaksanakan secara optimal. Belum optimalnya pembelajaran berbasis TIK diimplementasikan di SMASMA di Singaraja, karena sumber-sumber belajar seperti software pembelajaran berbasis TIK yang tersedia sangat terbatas. Di samping itu, software pembelajaran yang tersedia belum memberi peluang belajar secara mandiri, belum dilengkapi dengan pembelajaran yang bersifat interaktif yang memberi peluang kepada siswa untuk mengkonstruksi pengetahuannya secara mandiri sesuai dengan pandangan konstruktivisme. Berdasarkan kondisi ini perlu dikembangkan modul fisika kontekstual interaktif berbasis web dalam lingkungan PBL untuk dioperasikan pada jaringan internet. Modul tersebut berisikan sajian permasalahan kontekstual, miskonsepsi beserta sangkalan, konsep ilmiah, animasi/simulasi, contoh dan latihan soal kontekstual.

Tujuan yang ingin dicapai melalui penelitian ini, yaitu1) menyusun dan mengembangkan modul fisika kontekstual interaktif berbasis web untuk siswa kelas XII SMA, 2) menjelaskan perbedaan pengaruh antara modul fisika kontekstual interaktif berbasis web (MKIW) dan modul kontekstual konvensional (MKK) terhadap pemahaman konsep siswa dalam pembelajaran fisika, dan 3) menjelaskan perbedaan pengaruh antara MKIW dan MKK terhadap hasil belajar siswa dalam pembelajaran fisika.

Manfaat yang dapat dipetik dari penelitian ini, yaitu : pertama, modul fisika kontekstual interaktif berbasis web memberi peluang kepada siswa untuk meningkatkan pemahaman dan hasil belajar siswa. Modul ini mampu membangun jaringan materi yang baik. Menurut teori belajar kognitif, siswa belajar berarti membuat peta antara informasi yang sudah ada diketahui dengan informasi yang sedang dipelajari. Jadi, melalui modul berbasis web ini siswa sendirilah yang “membangun” pengetahuannya. Selama berinteraksi dengan modul berbasis web ini, siswa dilatih menggunakan kognisinya untuk mengorganisasikan informasi-informasi menurut kebutuhannya sebelum digunakan atau 
diterapkan pada tugas yang dihadapi. Proses belajar seperti ini hampir tidak ditemukan pada bahan ajar konvensional seperti pada buku-buku teks. Buku teks konvensional hanya menyediakan pemrosesan informasi dalam dua dimensi, yakni linier dan hirarkis. Sedangkan modul berbasis web menyediakan struktur dalam pemrosesan pemikiran manusia, melalui jaringan simpul-simpul dan tautan yang ada dimungkinkan navigasi tiga dimensi sepanjang informasi. Kedua, Modul berbasis web menyajikan materi-subjek dalam berbagai tautan dan pilihn memberikan fleksibelitas kepada pembaca untuk menyusun ulang materi sesuai yang diinginkan. Jadi, pada modul berbasis web ini, siswa bukan sekadar pembaca akan tetapi sekaligus sebagai “co-author” bahan bacaannya. Pembaca memiliki control yang kuat terhadap bacaannya. Merekalah yang akan menentukan urutan dari bahan ajar, yang berarti sekaligus menentukan konteks dari bacaannya. Ketiga, Pembelajaran dengan fasilitas modul berbasis web akan memberi peluang siswa untuk mengemukakan pendapat yang tidak diketahui oleh siswa lain. Artinya, siswa relatif lebih terbebas dari rasa malu atau rasa takut untuk mengemukakan pendapat. Hal ini terjadi karena komunikasi terjadi tidak secara langsung, melainkan melalui jaringan komputer. Oleh karena itu, pembelajaran dengan modul berbasis web, bisa mendorong pertukaran ide, meningkatkan partisipasi, meningkatkan keinginan untuk mencoba, dan meningkatkan fleksibelitas dalam kegiatan saling bertukar informasi.

\section{Metode Penelitian}

Penelitian ini dilakukan dalam dalam dua tahap, yaitu: pertama, pengembangan produk modul fisika kontekstual, dan kedua, eksperimen untuk menguji keunggulan komparatif produk.

Pengembangan produk menggunakan desain model Dick dan Carey. Proses pengembangan mendasarkan diri pada analisis kebutuhan. Salah satu pendukungnya adalah studi pendahuluan di SMA-SMA di Singaraja Bali. Proses pengembangan menggunakan instrumen-instrumen: angket fasilitas pendukung pembelajaran berbasis teknologi informasi dan komunikasi (TIK), angket kompetensi guru dan siswa dalam TIK, angket ahli isi, angket ahli media, angket ahli media, angket siswa perorangan, angket siswa kelompok kecil, dan anget respon implementasi pada pembelajaran. Instrumen-instrumen tersebut 
memenuhi persyaratan validitas isi. Studi pendahuluan melibatkan 320 siswa kelas XII SMA, 12 orang guru TIK, dan 30 guru fisika. Proses uji formatif melibatkan 3 ahli isi dan media pembelajaran, 3 ahli desain, 6 siswa perorangan, 12 siswa kelompok kecil, dan 3 orang guru. Dalam implementasi modul fisika kontekstual dilakukan dengan penelitian kuasi eksperimen dengan model unequivalence pretest-posttest control group design. Populasi penelitian adalah siswa-siswa kelas XII SMA di kota Singaraja pada semester I tahun 2010/2011. Pengambilan sampel eksperimen dilakukan dengan teknik random kelompok bertahap. Berdasarkan tehnik tersebut, terpilih kelompok-kelompok siswa yang belajar dengan fasilitas MKIW dan kelompok-kelompok siswa yang belajar dengan fasilitas MKK adalah adalah SMAN 1, SMAN 2, SMAN 3, dan SMAN 4 Singaraja. Jumlah anggota sample pada masing-masing kelompok adalah 120 siswa untuk MKIW, dan 120 siswa untuk MKK. Instrumen yang digunakan dalam eksperimen adalah tes pemahaman konsep dan tes hasil belajar. Instrumen tes pemahaman konsep terdiri 12 butir dengan internal consistency bergerak dari $r=0,40$ sampai dengan $r=0,69$, dan alpha Cronbach $=$ 0,713. Instrumen tes hasil belajar terdiri 12 butir dengan internal consistency bergerak dari $r=0,34$ sampai dengan $r=0,77$, dan alpha Cronbach = 0,733. Analisis data dilakukan dengan statistik deskriptif, Multivariat analysis of covariance (MANCOVA). Tehnik analisis menggunakan program SPSS 17.0 FW dengan pengujian hipotesis dilakukan pada taraf signifikansi 5\%.

\section{Hasil}

1) Hasil Pengembangan Modul Fisika Kontekstual berbasis web

Berdasarkan analisis data penelitian pendahuluan terungkap bahwa fasilitas penunjang pembelajaran berbasis web yang tersedia di SMA-SMA di Singaraja cukup memadai. Demikian pula dengan kompetensi Guru dan siswa dalam bidang TIK juga cukup memadai, namun pembelajaran berbasis web belum dapat dilaksanakan secara optimal. Belum optimalnya pembelajaran berbasis TIK diimplementasikan di SMA-SMA di Singaraja, karena sumber-sumber belajar seperti software pembelajaran berbasis TIK yang tersedia sangat terbatas. Di samping itu software pembelajaran yang tersedia belum memberi peluang belajar secara mandiri, belum dilengkapi dengan pembelajaran yang 
bersifat interaktif yang memberi peluang kepada siswa untuk mengkonstruksi pengetahuannya secara mandiri sesuai dengan pandangan konstruktivisme. Di lain fihak buku-buku penunjang pembelajaran fisika SMA yang konvensional khususnya yang bermuatan kontekstual yang mengarah bermakna juga sangat terbatas, belum diterapkannya secara optimal model pembelajaran kontekstual sebagai salah satu wujud komunitas belajar di SMA, dan kebiasaan para guru melakukan pembelajaran yang cenderung linier dan rutinitas, merupakan faktor utama yang mendorong pengembangan modul fisika kontekstual interaktif berbasis web dalam lingkungan pembelajaran berbasis masalah serta implementasinya untuk meningkatkan pemahaman konsep dan hasil belajar siswa kelas I SMA di kota Singaraja.

Pengembangan modul fisika kontekstual mengikuti model Dick \& Carey (1991). Berawal dari analisis kebutuhan lapangan, perencanaan, evaluasi, uji coba, dan revisi merupakan prosedur dalam mengembangkan dan memproduksi materi ajar tersebut. Prosedur pengembangan dilaksanakan dengan melibatkan para guru fisika, ahli isi pembelajaran, ahli media pembelajaran, ahli desain pembelajaran, dan siswa pemakai. Draft modul fisika kontekstual yang dihasilkan terdiri dari 8 modul. Masing-masing modul memuat antara 1-2 sub-modul. Masing-masing sub-modul memiliki sistimatika, yaitu (1) sajian masalah-masalah kontekstual atau pertanyaan-pertanyaan konseptual di awal sub bab, (2) sajian miskonsepsi dan sajian sangkalan, (3) sajian konsep atau prinsip ilmiah, (4) sajian contoh-contoh konseptual atau kontekstual, dan (5) sajian pertanyaan-pertanyaan di akhir teks yang dikemas dalam bentuk Lembaran Kerja Siswa (LKS). Modul fisika kontekstual interaktif berbasis web yang dikembangkan dalam penelitian ini dilengkapi dengan animasi, video, gambar, bunyi, dan variasi huruf/teks.

\section{2) Uji coba terbatas}

Hasil uji coba menunjukkan bahwa para evaluator memberikan penilaian dengan kategori baik dan amat baik. Hal ini menyatakan bahwa draf modul fisika kontekstual yang dihasilkan sangat layak digunakan sebagai penunjang pembelajaran fisika di SMA. Modul fisika kontekstual berikut perangkat pembelajarannya berupa LKS yang dikemas dalam 
bentuk animasi, video, gambar, bunyi, dan variasi huruf/teks, layak digunakan sebagai perangkat penunjang pembelajaran fisika di SMA. Di samping itu telah berhasil dikembangkan panduan modul fisika kontekstual interaktif berbasis web bagi siswa dan guru tentang implementasi modul dalam pembelajaran.

\section{3) Hail Kuasi Eksperimen}

Dari penelitian kuasi eksperimen diperoleh hasil seperti berikut. Pertama, profil pengetahuan awal siswa terhadap konsep-konsep kinematika dan dinamika sebagian besar masih diwarnai miskonsepsi (27,5\% untuk model MKIW dan 30,8\% untuk model MKK). Setelah eksperimen, profil miskonsepsi siswa mengalami penurunan menjadi 13,3\% untuk kelompok model MKIW dan 19,0\% untuk kelompok MKK. Secara deskriptif setelah perlakuan kelompok MKIW relatif lebih berhasil menurunkan jumlah siswa yang mengalami miskonsepsi dibandingkan dengan MKK. Kedua, uji komparasi produk menunjukkan hasil-hasil sebagai berikut. 1) Terdapat perbedaan signifikan pemahaman konsep antara kelompok MKIW dan MKK (F= 53,868; $\mathrm{p}<0,05$. Nilai rata-rata pemahaman konsep kelompok MKIW lebih tinggi dibandingkan dengan kelompok MKK $(\Delta \mu=5,525$; $\mathrm{SD}=0,573, \mathrm{p}<0,05) .2$ ) Terdapat perbedaan signifikan hasil belajar antara kelompok MKIW dan MKK ( $F=5,716 ; p<0,05$. Nilai rata-rata hasil belajar kelompok MKIW lebih tinggi dibandingkan dengan kelompok $\operatorname{MKK}(\Delta \mu=2,841 ; \mathrm{SD}=1,188, \mathrm{p}<0,05)$.

\section{4) Pembahasan}

Temuan penelitian ini sejalan dengan hasil-hasil penelitian sebelumnya (Williams, et al., 1998, Candiasa, 2005, Sujanem, et al., 2007a, Sujanem, et al., 2007b, Sujanem, et al., 2008) mengemukakan bahwa pemanfaatan modul kontekstual interaktif berbasis web dapat membantu siswa lebih memahami materi pembelajaran dan meningkatkan pemahaman konsep. Pembelajaran yang difasilitasi modul kontekstual interaktif berbasis web (mencakup, teks, simulasi, video, sound, dan animasi) dapat meningkatkan pemahaman konsep fisika (Dancy, \& Beichner, 2006, Sujanem, et al., 2007b, Sujanem, et al., 2008, Sujanem, et al., 2009).

Melalui web interaktif siswa belajar dalam suatu jalinan materi yang saling kaitmengkait (Candiasa, 2005, Sujanem, et al., 2007b). Lebih lanjut Mayes (2002) 
mengemukakan bahwa pembelajaran berbasis web memberikan peluang kepada siswa untuk mengakses informasi yang paling relevan untuk belajar yang diperlukan. Web interaktif juga menyediakan derajat interaktivitas yang tinggi, yang bermuara pada hasil belajar yang efektif (Mayes, 2002). Modul interaktif berbasis web merupakan media dinamis dan tidak linier, yang konsep-konsepnya saling berkaitan dengan penuh makna dalam berbagai bentuk hubungan (Antonenko, 2005, Turner dan Handler, 1997, McKnight, 1996, Sujanem, et al., 2007b, Sujanem, et al., 2008, Sujanem, et al., 200). Penyajian masalah yang konseptual dan kontekstual dalam modul kontekstual berbasis web ini memberi peluang kepada siswa untuk mengembangkan ketrampilan dalam merumuskan masalah, dan memecahkan masalah, merefleksikan belajarnya, dan mengembangkan pemahaman pada domain konten (Liu, et al, 2002, Jacobson \& Spiro, 1995, Sujanem, et al., 2007b). Pemahaman konsep secara mendalam merupakan langkah awal dalam pemerolehan hasil belajar.

Dengan sifat non linear, asosiatif, interaktif, dan kapasititas web yang interaktif menyediakan sumber yang kaya untuk mempresentasikan konsep di dalam konteks yang autentik dan menunjang belajar siswa sehingga mereka terlibat aktif dalam aktivitas kognitif yang kompleks dan pengarahan diri (Williams, et al, 1998).

Melalui web, siswa dapat mengakses sumber belajar di dalam pesan atau tautan yang telah ditetapkan, dan siswa dapat melakukan navigasi pada lingkungan yang tak linear (Burton, et al, dalam Williams, et al, 1998). Dukungan berbagai jenis media dan kemungkinan navigasi non linear secara khusus berguna di dalam mengkreasi lingkungan PBL berbasis komputer (Williams, et al, 1998:468). Sifat-sifat non linear web interaktif adalah sesuai dengan karakteristik PBL. Dengan sifat-sifat non linear dari web ini akan memberi peluang kepada siswa untuk mengeksplorasi lingkungan PBL, mengakses berbagai sumber sesuai yang diinginkan. Web interaktif mempunyai potensi untuk membuat alat kognitif yang siap digunakan siswa. Web interaktif dapat menyuguhkan masalah-masalah real lewat simulasi, atau video. Di samping itu, web dapat mempresentasikan skenario, dan mempunyai keunggulan dalam memberi peluang kepada siswa untuk mengeksplorasi lingkungan di mana skenario dirancang. Skenario ini dapat 
mencerminkan proses mana siswa menggunakan alamat problem di dalam setting kehidupan nyata. Web interaktif juga dapat memfasilitasi perkembangan autentik dalam lingkungan belajar (Williams, et al, 1998). Dengan demikian, siswa terlibat aktif dalam PBL, mereka dapat mengumpulkan data dan mengakses sumber belajar. Hal ini menunjukkan derajat kontrol yang tinggi bagi siswa untuk mengakses sumber-sumber yang diperlukan, mengontrol lebih banyak seluruh belajarnya. Dengan demikian, siswa menjadi aktif di dalam pengambilan keputusan.

Pengkemasan modul físika kontekstual berbasis web dalam lingkungan pembelajaran berbasis masalah atau problem based learning (PBL) memberi peluang kepada siswa untuk peka pada masalah-masalah real dan memecahkan masalah, merumuskan masalah, mencari solusi, dan membangun pamahaman. Dalam pembelajaran berbasis masalah, siswa diberikan tanggung jawab utama untuk membentuk dan mengarahkan pembelajarannya sendiri, menggunakan kelompok-kelompok kooperatif dalam pembelajaran, dan menuntut siswa untuk menampilkan apa yang telah mereka pelajari melalui hasil atau penampilan (Savoi, 1994). Demikian pula, hasil penelitian Tau dan Gunstone (dalam Kearney, 2001) menunjukkan bahwa penggunaan komputer dalam kegiatan pembelajaran Fisika memberikan peluang kepada siswa untuk mengerjakan variasi metode pemahaman dan untuk menginterpretasikan table bilangan, grafik, persamaan, atau diagram. Eadie (2001) menunjukkan bahwa pembelajaran yang memanfaatkan teknologi informasi dan komunikasi berpengaruh terhadap peningkatan pemahaman dan hasil belajar siswa.

Berdasarkan pembahasan tersebut, maka modul físika kontekstual interaktif berbasis web dapat diacu sebagai fasilitas pembelajaran alternatif untuk mengoptimalkan pembelajaran fisika dalam pencapaian pemahaman konsep dan hasil belajar.

Secara teoritis, model modul físika kontekstual interaktif berbasis web menyiapkan peluang masalah-masalah real yang dikemas dalam bentuk video, animasi, atau multimedia, menyediakan peluang materi yang saling bertautan yang mudah diakses, materi ajar yang bersifat non linear yang memberi peluang siswa dalam mengkonstruksi makna, menyediakan model laboratorium, dan menyediakan pemecahan masalah dalam bentuk 
LKS yang dikemas berupa hiperteks, gambar, video, dan animasi, yang dapat memfasilitasi siswa dalam perolehan pemahaman konsep dan hasil belajar (Candiasa, 2005, Theyßen,2006, Jacobson, 2006, Mayes, 2003, Antonenko, 2005, Sujanem, et al., 2007a, Sujanem, et al., 2007b, Sujanem, et al., 2008, Sujanem, et al., 2009). Model modul kontekstual linear adalah bahan ajar linear yang berisikan masalah-masalah real, materi ajar, latihan/tugas, dan LKS yang dikemas dalam bentuk teks dan gambar.

\section{Penutup}

Berdasarkan hasil-hasil penelitian pengembangan dan implementasinya dalam pembelajaran dengan pola penelitian kuasi eksperimen, dapat ditarik kesimpulan sebagai berikut. Pertama, hasil penelitian pengembangan produk modul fisika kontekstual mengungkapkan temuan, yaitu: telah berhasil dikembangkan modul fisika berikut lembaran kerja siswa kontekstual interaktif berbasis web yang memiliki kelayakan untuk diimplementasikan dalam pembelajaran. Kedua, telah berhasil dikembangkan panduan modul fisika kontekstual interaktif berbasis web bagi guru yang yang berisikan tentang panduan tentang implementasi modul dalam pembelajaran. Ketiga, telah berhasil dikembangkan panduan modul fisika kontekstual interaktif berbasis web bagi siswa yang yang berisikan tentang panduan tentang implementasi modul dalam pembelajaran. Keempat, dalam uji komparasi keunggulan produk melalui penelitian eksperimen kuasi, dapat diungkapkan simpulan-simpulan sebagai berikut. (1) Terdapat perbedaan pemahaman konsep antara siswa yang menggunakan model modul fisika kontekstual interaktif berbasis web dan yang menggunakan model modul físika kontekstual konvensional. Siswa yang menggunakan model modul fisika kontekstual interaktif berbasis web menunjukkan pemahaman konsep yang lebih baik dibandingkan dengan siswa yang menggunakan model modul físika kontekstual konvensional. (2) Terdapat perbedaan hasil belajar fisika antara siswa yang menggunakan model modul fisika kontekstual interaktif berbasis web dan yang menggunakan model modul físika kontekstual konvensional. Siswa yang menggunakan model modul fisika kontekstual interaktif berbasis web menunjukkan hasil relajar fisika yang lebih baik dibandingkan dengan siswa yang menggunakan model modul físika kontekstual konvensional 
Kelima, modul fisika kontekstual interaktif berbasis web untuk siswa kelas XII SMA yang dihasilkan dari penelitian Hibah Bersaing Dikti tahun angaran 2010 memiliki kelayakan sebagai fasilitas belajar bagi siswa kelas XII SMA dan keunggulan komparatif dibandingkan dengan modul fisika yang dikonstruksi secara konvensional.

Berdasarkan hasil-hasil penelitian, kendala yang dialami, dan cara mengatasi kendala tersebut, dapat diajukan saran-saran penelitian seperti berikut. Pertama, modul fisika SMA sebaiknya dikembangkan secara ekplisit memuat materi pembelajaran yang kontekstual. Seiring dengan perkembangan teknologi informasi dan komunikasi, sebaiknya materi ajar fisika yang kontekstual tersebut dikemas dalam bentuk web interaktif. Pembelajaran fisika di SMA sebaiknya dilakukan dengan model pembelajaran berbasis masalah yang merupakan salah satu strategi pendekatan kontekstual. Kedua, model modul físika kontekstual interaktif berbasis web dalam lingkungan pembelajaran berbasis masalah tepat diacu sebagai alternatif pembelajaran fisika khususnya dalam pencapaian pemahaman konsep dan hasil belajar. Ketiga, dalam implementasi model modul físika kontekstual interaktif berbasis web tersebut, disarankan agar terlebih dahulu menggali masalah-masalah yang real yang sifatnya kompleks tak terstruktur, kemudian pengkemasan masalah-masalah tersebut hendaknya lebih banyak dalam bentuk video, sehingga masalah-masalah disajikan benar-benar autentik yang ada di sekitar siswa. Keempat, dalam penelitian ini, variabelvariabel pemahaman konsep dan hasil belajar dianggap telah mempresentasikan perolehan belajar fisika. Namun, representasi hanya terbatas pada cakupan materi usaha dan energi untuk pelajaran fisika kelas XII SMA. Untuk penelitian lebih lanjut perlu dipertimbangkan untuk melakukan pengujian keefektifan model modul físika kontekstual interaktif berbasis web dalam pencapaian pemahaman konsep dan hasil belajar pada cakupan materi yang lebih luas dalam mata pelajaran fisika. Kelima, variabel bebas yang diuji dalam penelitian ini terbatas pada pemahaman konsep dan hasil belajar fisika siswa. Untuk penelitian lebih lanjut perlu dipertimbangkan untuk melakukan pengujian keefektifan model modul físika kontekstual interaktif berbasis web dalam pencapaian motivasi, minat, dan sikap terhadap belajar fisika. 


\section{DAFTAR PUSTAKA}

Antonenko,P. 2005. Considering the Learner in Educational Hypermedia Design: Cognitive Load or Cognitive Flexibility? Iowa State University Human Komputer Interaction Technical Report ISU-HCI-2005-02

Brooks,J.G.,\& Brooks,N.G.1993. In search of understanding : The case for constructivist classrooms. Virginia : Association for supervision and Curriculum Development.

Candiasa, M. 2004. Pembelajaran dengan modul berbasis web. Jurnal Pendidikan dan Pengajaran No 3 Th XXXVII Juli 2004 hal 1-12.

Candiasa, M. 2005. Implementasi Jaringan Semantik dengan hypermedia. Jurnal Pendidikan Teknologi dan Kejuruan Vol 2 No 1 Januari 2005 hal 64-72.

Dancy, M.H \& Beichner. R.2006. Impact of animation on assessment of conceptual understanding in physics. PHYSICAL REVIEW SPECIAL TOPIKS - PHYSICS EDUCATION RESEARCH 2, 010104 2006 hal 1-7

Duffy, T.M. \& Cunningham,D.J. 1996. Constructism:Implication for the design and delivery for instruction. Handbook of Research for Educational Communication and Technology, ed. David H. Jonassen. London : Prentice Hall International.

Gijselaers, W.H.1996. Connecting Problem-Based Practices with Educational Theory. Ne Diection ffor Teaching and Learning No. 68. p. 13-21.Jossey Bass Publisher.

Hardjito. 2005. Jurnal Internet untuk Pembelajaran, www.pustekkom.go.id

Ibrahim, M., \& Nur, M. 2004. Pembelajaran berdasarkan masalah.Unesa-University Press. Surabaya.

Jacobson, M.J., 2006. Running head : hypermedia system for problem-based learning: theory, research, and learning emergeing scientific conceptual perspectives.

Kearney, M., Treagust, F.D., Yeo, S., Zadnik, M. Student and teacher perceptions of the use of multimedia supported predict-observe-explain task to probe understanding.

Lawson, A.E. 1998. Science Teaching and The Development of Thinking. California:Wadworth Publishing Company.

Liu,M. 2005. Alien Rescue: A Problem-Based Learning Environment for Middle School Science. 
http://tip.missouri.edu/tip.nsf/0/D03C1427DD93E76F86256BE7007FB59F? OpenDocument

McKnight, C. \& Dillon, A. 1996.User-Centered Design Hypertext/Hypermedia for Education. Handbook of Research for Educational Communication and Technology, ed. David H. Jonassen. London : Prentice Hall International.

Novak, J.D. \& Gowin.D.B.1985. Learning how to learn. Ne York : Cambride University Press.

Oliver, R., \& Herrington, J. (2003). Exploring technology-mediated learning from a pedagogical perspective. Interactive Learning Environments, 1 (2), 111-126.

Santyasa, I.W.2004. Pengaruh Model dan Seting Pembelajaran terhadap remediasi miskonseps, pemahaman konsep dan hasil belajar fisika pada siswa SMU. Disertasi (tidak dipublikasikan). Program Doktor Teknokogi Pembelajaran Program Pasca Sarjana Universitas Negeri Malang.

Sujanem, R. 2006. Implementasi Strategi Siklus Belajar 5E Berbantuan Web dalam Pembelajaran Fisika Statistik Sebagai Upaya Meningkatkan Hasil Belajar Mahasiswa Jurusan Fisika IKIPN Singaraja. Laporan Penelitian IKIP Negeri Singaraja. Lemlit IKIP Negeri Singaraja.

Sujanem, R. 2002. Optimimalisasi Pendekatan STM dengan Strategi Belajar Berbasis Masalah dalam Pembelajaran Listrik Statis dan Dinamis sebagai Upaya Mengubah Miskonsepsi, Meningkatkan Literasi Sains dan Teknologi Siswa Kelas $\mathrm{II}_{3}$ SMUN 1 Singaraja. Laporan Penelitian IKIP Negeri Singaraja. Lemlit IKIP Negeri Singaraja.

Sujanem, R. 2003. Implementasi Pendekatan Kontekstual Dalam Pembelajaran Fisika Sebagai Upaya Untuk Meningkatkan Sikap Ilmiah, Aktivitas, dan Hasil Belajar Fisika Siswa Kelas IB SMPN 6 Singaraja. Laporan Penelitian IKIP Negeri Singaraja. Lemlit IKIP Negeri Singaraja.

Sujanem, R., Lagasudha, N., \& Susila, K. 2007ª Pengembangan materi ajar e-learning físika kontekstual dalam pembelajaran berbasis masalah untuk meningkatkan motivasi dan hasil belajar siswa SMA. Laporan Research for Comdev I-MHERE undiksha tahun 2007.

Sujanem, R., Suwindra, I.N.P, \& Subratha, N. 2007b. Pengaruh bahan ajar berdesain hipermedia dan seting pembelajaran terhadap pemahaman konsep dan hasil belajar siswa SMPN di Singaraja. Laporan Penelitian PHK-A2 Jurdik Físika tahun 2007. 
Sujanem, R Suwindra, I.N.P, Tika,K. 2008. Pengembangan Modul Fisika Kontekstual interaktif berbasis Web Untuk Meningkatkan Pemahaman Konsep dan Hasil Belajar Fisika Siswa SMA di Singaraja. Laporan Penelitian Hibah Bersaing Tahun Pertama (2008). Lemlit Undiksha Singaraja.

Sujanem, R Suwindra, I.N.P, Tika,K. 2009. Pengembangan Modul Fisika Kontekstual interaktif berbasis Web Untuk Meningkatkan Pemahaman Konsep dan Hasil Belajar Fisika Siswa SMA di Singaraja. Laporan Penelitian Hibah Bersaing Tahun Kedua (2009). Lemlit Undiksha Singaraja.

Turner, S. V., \& Handler, M. G. (1997). Hypermedia in education: Children as audience or authors? Journal of Information Technology for Teacher Education, 6 (1), 25-35.

Theyßen,H. 2003. Students' Attitudes Towards the Hypermedia Learning Environment "Physics for Medical Students" [Online]. EURODOL .Tersedia: [http://www.idn.uni-bremen.de/]

William, D.C., Pedersen, S., \& Liu, M. 1998. An Evaluation of the Use of Problem-Based Learning Software By Middle School Students. Journal of Universal Komputer Science vol 4 issue 4 hal 466-483. 